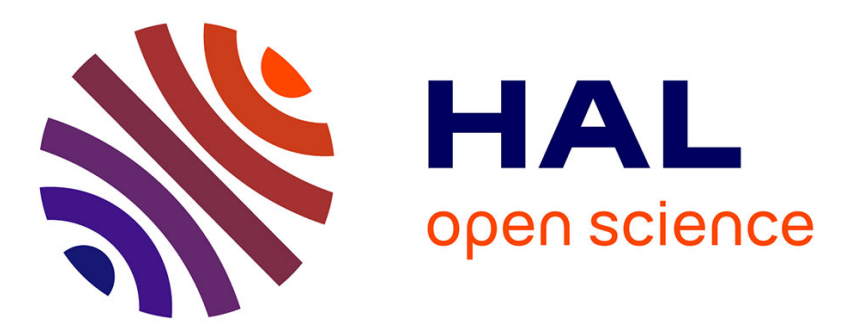

\title{
Acquisition of enteric pathogens by pilgrims during the 2016 Hajj pilgrimage: A prospective cohort study
}

Doudou Sow, Fabiola Dogue, Sophie Edouard, Tassadit Drali, Segolene

Prades, Emilie Battery, Saber Yezli, Badriah Alotaibi, Cheikh Sokhna, Didier

Raoult, et al.

\section{To cite this version:}

Doudou Sow, Fabiola Dogue, Sophie Edouard, Tassadit Drali, Segolene Prades, et al.. Acquisition of enteric pathogens by pilgrims during the 2016 Hajj pilgrimage: A prospective cohort study. Travel Medicine and Infectious Disease, 2018, 25, pp.26-30. 10.1016/j.tmaid.2018.05.017 . hal-01910329

\section{HAL Id: hal-01910329 \\ https://hal.science/hal-01910329}

Submitted on 12 Apr 2019

HAL is a multi-disciplinary open access archive for the deposit and dissemination of scientific research documents, whether they are published or not. The documents may come from teaching and research institutions in France or abroad, or from public or private research centers.
L'archive ouverte pluridisciplinaire HAL, est destinée au dépôt et à la diffusion de documents scientifiques de niveau recherche, publiés ou non, émanant des établissements d'enseignement et de recherche français ou étrangers, des laboratoires publics ou privés. 


\title{
Acquisition of enteric pathogens by pilgrims during the 2016 Hajj pilgrimage: A prospective cohort study
}

\author{
Doudou Sow $^{\mathrm{a}, \mathrm{b}}$, Fabiola Dogue ${ }^{\mathrm{a}}$, Sophie Edouard ${ }^{\mathrm{a}}$, Tassadit Drali ${ }^{\mathrm{a}}$, Ségolène Prades ${ }^{\mathrm{a}}$, \\ Emilie Battery ${ }^{a}$, Saber Yezli ${ }^{\mathrm{c}}$, Badriah Alotaibi ${ }^{\mathrm{c}}$, Cheikh Sokhna ${ }^{\mathrm{a}}$, Didier Raoult ${ }^{\mathrm{a}}$, Philippe Parola ${ }^{\mathrm{a}}$, \\ Philippe Gautret ${ }^{\mathrm{a}, *}$
}

a Aix Marseille Univ, IRD, AP-HM, SSA, VITROME, IHU-Méditerranée Infection, Marseille, France

${ }^{\mathrm{b}}$ Service de Parasitologie-Mycologie, Faculté de médecine, Unversité Cheikh Anta Diop, Dakar, Senegal

${ }^{\mathrm{c}}$ The Global Centre for Mass Gatherings Medicine, Ministry of Health, Riyadh, Saudi Arabia

\section{A R T I C L E I N F O}

\section{Keywords:}

Hajj

Mass gathering

Diarrhea

Escherichia coli

PCR

\begin{abstract}
A B S T R A C T
Background: Diarrhea can be frequent among Hajj pilgrims; however, data on its etiology are very limited. Patients and methods: A prospective cohort study was conducted among Hajj pilgrims in 2016. Medical follow-up and systematic rectal swabing were performed before leaving France and before leaving Saudi Arabia. Potential pathogens were identified using the BioFire FilmArray ${ }^{\circ}$ Gastrointestinal multiplex qualitative PCR panel. Results: 117 pilgrims were included and 13.7\% experienced diarrhea during Hajj. Of the pre-Hajj samples, $32.5 \%$ were positive for at least one pathogen compared to $50 \%$ of post-Hajj samples ( $\mathrm{p}=0.0033$ ). Diarrhea associated Escherichia coli strains, notably enteropathogenic E. coli (EPEC), enteroaggregative E. coli (EAEC), and Shiga-like toxin-producing E. coli, were acquired by $29.9 \%, 10.2 \%$, and $6.5 \%$ pilgrims, respectively. Pilgrims with resolved diarrhea were significantly more likely to have post-Hajj EAEC positive samples, compared with those who did not suffer diarrhea (55.6\% vs $16.5 \%)$. We found a lower prevalence of EPEC (22.5\%) in pilgrims who declared washing their hands more frequently at the Hajj than usually as compared to others (40.0\%).

Conclusion: The acquisition of diarrhea associated $E$ coli by Hajj pilgrims is of major concern given the high prevalence rate of third-generation cephalosporin-resistant E. coli in Saudi Arabia.
\end{abstract}

\section{Introduction}

Each year, 2-3 million Muslims from more than 180 countries gather in the Kingdom of Saudi Arabia (KSA) to perform the pilgrimage to Mecca, (the "Hajj"). The presence of a large number of pilgrims from many parts of the world in congested and crowded areas greatly increases the risk of spreading infectious diseases, particularly respiratory and gastro-intestinal diseases [1]. Available studies on the clinical prevalence of diarrhea among Hajj pilgrims indicate a mean prevalence of $2 \%$ with the highest prevalence $(23 \%)$ reported among a group of French pilgrims in 2013. However, data on the etiology of diarrheal disease at the Hajj are very limited [2]. One study screened fecal samples from pilgrims with medically attended diarrheal illness from 40 countries during the 2011-2013 Hajj. Patient stools were screened for Escherichia coli pathotypes, Campylobacter jejuni, Shigella spp., Salmonella spp. Yersinia enterocolitica and Vibrio cholerae using a combination of previously established multiplex PCR assays. Cryptosporidium spp., Giardia lamblia, norovirus, rotavirus, adenovirus and astrovirus were detected using commercial antigenic detection tests.

Bacteria were the main agents detected with a prevalence of Salmonella spp. of $11.4 \%$, while diarrhea associated $E$. coli prevalence ranged between 1.3 and $8.8 \%$ according to pathotypes [3].

Recently studies on returning French pilgrims have shown that participation in the Hajj increases carriage rates of enteric pathogens including Tropheryma whipplei [4], multidrug-resistant nontyphoidal Salmonella [5], CTX-M type extended-spectrum $\beta$-lactamase producing E. coli and Klebsiella pneumoniae [6], colistin-resistant $E$. coli and $K$. pneumoniae and carbapenemase-producing E. coli $[7,8]$. Moreover, acquisition of CTX-M genes at the Hajj was associated with the occurrence of diarrhea and use of $\beta$-lactams [9]. Therefore, diarrhea at the Hajj is not only a concern for the pilgrims' health during their stay in Saudi Arabia but also a matter of public health with respect to potential dissemination of drug-resistant pathogens.

The aims of the present study were to evaluate the carriage of pathogens commonly associated with travelers' diarrhea among Hajj pilgrims with and without diarrheal symptoms during their stay in Saudi

\footnotetext{
* Corresponding author. VITROME, Institut Hospitalo-Universitaire Méditerranée Infection, 19-21 Boulevard Jean Moulin, 13385, Marseille Cedex 05, France.

E-mail address: philippe.gautret@ap-hm.fr (P. Gautret).
} 
Arabia, and to better understand the dynamics of acquisition of enteric pathogens in this particular setting. We hypothesized that several factors may influence the outcome of gastrointestinal symptoms or pathogen carriage during the stay, including preventive measures, and use of antibiotics.

\section{Materials and methods}

\subsection{Study population}

The study was conducted among French Hajj pilgrims travelling together to Mecca, KSA, from August 27 to September 20, 2016, with one specialized travel agency in Marseille. Pilgrims stayed in the same hotels and tents all over their stay in Saudi Arabia with breakfast included. Pilgrims were free to eat in restaurants of their choice for lunch and diner while staying in Mecca (from August 27 to September 9) and in Medina (from September 15 to September 20). Pilgrims eat the same food during their stay in Mina, Arafat and Muzdalifah (from September 10 to September 14). Pilgrims older than 18 years were included on a voluntary basis, and participants were asked to sign a written consent form. Upon inclusion, the participants were questioned using a standardized pre-travel questionnaire, which included demographic data and chronic medical conditions. Health issues that occurred during the stay in the KSA were recorded by a medical doctor who travelled with the pilgrims. Diarrhea was defined by at least three loose or liquid stools per day. Each individual was classified in one of the three following categories: asymptomatic (those who did not experience any diarrheal symptoms during the entire stay in KSA), resolved diarrhea (those who experienced diarrhea during travel, but who recovered before return to France) and ongoing diarrhea (those with ongoing diarrheal symptoms once back in France). Nausea, vomiting, abdominal pain and constipation were also recorded. Overweight and obesity were defined by a body mass index of $25-30$ and $>30$, respectively. Compliance with preventive measures was investigated by questionnaires just before leaving KSA (higher or lower frequency of hand washing with soap during the stay in KSA, compared to usual frequency at home and use or not of hand disinfectant during the stay). Use of antibiotics in KSA was also recorded through questionnaires.

The protocol was approved by our Institutional Review Board (July 23, 2013; reference No. 2013-A00961-44). It was performed in accordance with the good clinical practices recommended by the Declaration of Helsinki and its amendments. All participants gave written informed consent.

\subsection{Sample collection}

The procedure included a rectal swab before departure and a rectal swab upon return. Rectal swabs were self-collected by each participant by using commercial rigid cotton-tipped swab applicators (Medical Wire \& Equipment, Wiltshire, UK), 10 days before departing from France (pre-Hajj specimens) and just 1 day before leaving the KSA (post-Hajj specimens). The swab was inserted past the anal sphincter (rotated for approximately $5 \mathrm{~s}$ ) and replaced in its hermetic tube containing viral transport media (Sigma Virocult ${ }^{\circ}$ ). This standardized procedure was previously explained to the pilgrims by the investigators. Swabs were kept at room temperature before being transported to our laboratory in Marseille for storage in a $-80^{\circ} \mathrm{C}$ freezer within $48 \mathrm{~h}$ of collection.

\subsection{Identification of gastro-intestinal pathogens}

The analyses were carried out with a validated multiplex qualitative PCR method (FilmArray ${ }^{\circ}$ GI Panel, bioMérieux, Marcy L'Etoile, France) according to the manufacturer's instructions on a FilmArray 2.0 system. Hands-on time is less than $3 \mathrm{~min}$ and run time is approximately $1 \mathrm{~h}$. The FilmArray ${ }^{\oplus}$ Gastrointestinal panel (BFGP, bioMérieux) included the following bacterial, viral and parasitic targets: Campylobacter spp. (C. jejuni, C. coli, and C. upsaliensis), Clostridium difficile toxin A/B, enteroaggregative $E$. coli (EAEC), enteropathogenic $E$. coli (EPEC), enterotoxigenic E. coli (ETEC), Shiga-like toxin-producing E. coli (STEC), Shigella/enteroinvasive E. coli (EIEC), Plesiomonas shigelloides, Salmonella spp., Vibrio spp. (V. parahaemolyticus, V. vulnificus, V. cholerae), Y. enterocolitica, adenovirus F40/41, astrovirus, norovirus GI/ GII, rotavirus A, sapovirus, Cryptosporidium spp., Cyclospora cayetanensis, Entamoeba histolytica and G. lamblia.

\subsection{Statistical analysis}

Characteristics of the study population were summarized as frequencies and percentages for qualitative variables and as means, median and range for quantitative variables. Acquisition of pathogens was defined as the absence of a given pathogen in pre-Hajj stool samples and the presence of this pathogen in post-Hajj samples. The Student's $t$-test test and Wilcoxon test, when appropriate, were applied to analyze the categorical variables. $\mathrm{P}$ values of 0.05 or less were considered significant. Statistical analyses were performed using SPSS (version 17.2).

\section{Results}

\subsection{Demographics and gastro-intestinal symptoms}

A total of 117 pilgrims were included upon departure from France (Table 1). The mean age was 61.0 years, and $46.2 \%$ were males. Most pilgrims were born in North Africa (89.8\%) and had settled in France more than 20 years ago. Prevalence of chronic conditions was as follows: diabetes $(31,26.5 \%)$, hypertension $(26,22.2 \%)$, chronic respiratory disease $(11,9.4 \%)$, chronic cardiac disease $(4,3.4 \%)$, immunosuppressive condition (1, 0.9\%), overweight $(47,40.2 \%)$ and obesity $(38,32.4 \%)$. A total of $75(64.1 \%)$ pilgrims declared having used hand gel disinfectant during their stay and 51 (43.6\%) declared having washed their hands more frequently than usually during their stay.

None of the pilgrims had digestive symptoms on leaving France; 16 (13.7\%) experienced diarrhea in KSA and none of them took antibiotics for diarrhea; 31 (26.5\%) pilgrims, however, took antibiotics during their stay, due to a respiratory tract infection. Overall, 16 pilgrims (13.7\%) reported nausea, 6 (5.1\%) vomiting, 9 (7.7\%), abdominal pain and $13(11.1 \%)$ constipation. Among 16 pilgrims with diarrhea, 5 reported nausea, 4 vomiting, 7 abdominal pain and 6 constipation. None were hospitalized.

Table 1

Demographic and baseline characteristics of the study participants $(\mathrm{N}=117)$.

\begin{tabular}{ll}
\hline Characteristics & No. (\%) unless otherwise specified \\
\hline $\begin{array}{l}\text { Mean age (IqR) } \\
\text { Gender }\end{array}$ & 61.0 years (55-69 years) \\
Male & \\
Female & $54(46.2)$ \\
Birthplace & $63(53.8)$ \\
Algeria & \\
Tunisia & $62(53.0)$ \\
Morocco & $29(24.8)$ \\
Metropolitan France & $14(12.0)$ \\
Other & $7(5.9)$ \\
Clinical symptoms during travel & $5(4.4)$ \\
Diarrhea & $16(13.7)$ \\
Nausea & $16(13.7 \%)$ \\
Vomiting & $6(5.1 \%)$ \\
Abdominal pain & $9(7.7 \%)$ \\
Constipation & $13(11.1 \%)$ \\
\hline
\end{tabular}

${ }^{\text {a }}$ Egypt $(\mathrm{n}=1)$, Mali $(\mathrm{n}=1)$, Senegal $(\mathrm{n}=3)$. 
Table 2

Frequency of pathogens detected before and after travelling to Saudi Arabia.

\begin{tabular}{|c|c|c|c|c|}
\hline & $\begin{array}{l}\text { Before travel }(\mathrm{N}=114) \\
\text { Number of individuals with positive sample } \\
\text { (prevalence } \% \text { ) }\end{array}$ & $\begin{array}{l}\text { After travel }(\mathrm{N}=112) \\
\text { Number of individuals with positive sample } \\
\text { (prevalence \%) }\end{array}$ & $\begin{array}{l}\text { Acquisition rate } \\
(\mathrm{N}=108)\end{array}$ & $\mathrm{p}$ value (before versus after) \\
\hline \multicolumn{5}{|l|}{ Bacteria } \\
\hline Campylobacter spp. & 0 & 0 & 0 & - \\
\hline Clostridium difficile & 0 & $3(2.7)$ & $3(2.8)$ & $0.08^{*}$ \\
\hline EAEC $^{\mathrm{a}}$ & $20(17.5)$ & $21(18.7)$ & $11(10.2)$ & $0.66^{*}$ \\
\hline EPEC $^{\mathrm{b}}$ & $16(14.0)$ & $40(35.7)$ & $32(29.6)$ & $0.0005^{*}$ \\
\hline ETEC $^{\mathrm{C}}$ & $2(1.8)$ & $4(3.6)$ & $4(3.7)$ & $0.42^{*}$ \\
\hline STEC $^{\mathrm{d}}$ & $7(6.1)$ & $8(7.1)$ & $7(6.5)$ & $0.78^{*}$ \\
\hline EIEC $^{\mathrm{e}}$ & $1(0.9)$ & 0 & 0 & - \\
\hline Plesiomonas shigelloides & $1(0.9)$ & 0 & 0 & - \\
\hline Salmonella spp. & 0 & 0 & 0 & - \\
\hline Vibrio spp. & 0 & 0 & 0 & - \\
\hline Yersinia enterocolytica & 0 & 0 & 0 & - \\
\hline At least one bacteria & $36(31.6)$ & $54(48.2)$ & 45 (41.7) & $0.0088^{* *}$ \\
\hline \multicolumn{5}{|l|}{ Virus } \\
\hline Adenovirus & 0 & 0 & 0 & - \\
\hline Astrovirus & 0 & 0 & 0 & - \\
\hline Norovirus & 0 & $3(2.7)$ & $3(2.7)$ & $0.08^{*}$ \\
\hline Rotavirus & 0 & 0 & 0 & - \\
\hline Sapovirus & $2(1.8)$ & 0 & 0 & - \\
\hline At least one virus & $2(1.8)$ & $3(2.7)$ & $3(2.7)$ & $0.08^{*}$ \\
\hline \multicolumn{5}{|l|}{ Parasite } \\
\hline Cryptosporidium spp. & 0 & 0 & 0 & - \\
\hline Cyclospora cayetanensis & 0 & 0 & 0 & - \\
\hline Entamoeba histolytica & 0 & 0 & 0 & - \\
\hline Giardia lamblia & $1(0.9)$ & 0 & 0 & - \\
\hline At least one parasite & $1(0.9)$ & 0 & 0 & - \\
\hline At least one pathogen & $37(32.5)$ & $56(50.0)$ & $47(43.5)$ & $0.0033^{* *}$ \\
\hline At least two pathogens & $10(8.8)$ & $21(18.8)$ & $11(10.2)$ & 0.66 \\
\hline
\end{tabular}

*Wilcoxon test.

**Student's $t$-test.

a Enteroaggregative Escherichia coli.

b Enteropathogenic E. coli.

c Enterotoxigenic E. coli.

d Shiga-like toxin-producing E. coli.

e Shigella/enteroinvasive $E$. coli.

\subsection{Pathogens in rectal samples}

Rectal swabs were obtained from 114 pilgrims (97.4\%) before travelling to KSA and from $112(95.7 \%)$ before leaving KSA for France. Among them, 108 individuals (92.3\%) had paired samples, allowing calculation of acquisition rates.

The prevalence of each potential pathogen detected is presented in Table 2. Of the pre-Hajj samples, 37 (32.5\%) were positive while a pathogen was found in $56(50 \%)$ of post-Hajj samples $(\mathrm{p}=0.0033)$. Overall, the acquisition rate of at least one pathogen was $43.5 \%$. Campylobacter spp., Salmonella spp., Vibrio spp., Y. enterocolytica, adenovirus, astrovirus, rotavirus, Cryptosporidium spp., C. cayetanensis and $E$. histolytica were not detected at any point of the study. P. shigelloides, EIEC, G. lamblia and sapovirus were found in only 5 pilgrims before departing from France and were not detected following the stay in KSA. The most prevalent organisms detected before and after the Hajj were notably EPEC, EAEC, and STEC (14.0\%, $17.5 \%, 6.1 \%$ and $35.7 \%$, $18.7 \%, 7.1 \%$, respectively) with acquisition rates of respectively $29.9 \%$, $10.2 \%$, and $6.5 \%$. Only EPEC acquisition was statistically significant $(\mathrm{p}=0.0005)$. Some pilgrims also acquired $C$. difficile, ETEC, and norovirus with rates ranging between $2.7 \%$ and $3.7 \%$. Multiple pathogen detections (Table 3) accounted for 10 out of 37 positive samples in pilgrims before travel $(27.0 \%)$ and 21 out of 54 positive samples in pilgrims after travel (38.9\%). The most frequent association was EAEC and EPEC.

Among the 112 pilgrims with post-Hajj samples available, 97 did
Table 3

Frequency of multiple pathogen combinations.

\begin{tabular}{|c|c|c|}
\hline & Before travel & After travel \\
\hline $\mathrm{EAEC}^{\mathrm{a}}+\mathrm{EPEC}^{\mathrm{b}}$ & 3 & 11 \\
\hline $\mathrm{EAEC}+\mathrm{EPEC}+$ ETEC $^{\mathrm{c}}$ & - & 1 \\
\hline EAEC + EPEC + sapovirus & 2 & - \\
\hline EAEC + EPEC + norovirus & & 1 \\
\hline EAEC + ETEC & - & 1 \\
\hline $\mathrm{EAEC}+\mathrm{ETEC}+\mathrm{EIEC}^{\mathrm{d}}$ & 1 & - \\
\hline EAEC + STEC ${ }^{\mathrm{e}}$ & 2 & 4 \\
\hline EAEC + Plesiomonas shigelloides & 1 & - \\
\hline EPEC + ETEC & 1 & 2 \\
\hline EPEC + Clostridium & & 1 \\
\hline Total multiple pathogens detected & 10 & 21 \\
\hline
\end{tabular}

a Enteroaggregative Escherichia coli.

${ }^{\mathrm{b}}$ Enteropathogenic E. coli.

${ }^{\text {c }}$ Enterotoxigenic E. coli.

d Shigella/enteroinvasive E. coli.

e Shiga-like toxin-producing E. coli.

not suffer from diarrhea during their stay in Saudi Arabia, 9 had a resolved diarrhea at the time of sampling and 6 had an ongoing diarrhea. EAEC, STEC and norovirus prevalence was higher in pilgrims who had diarrhea during travel $(33.3 \%, 20.0 \%, 6.7 \%)$ compared to those who had no diarrhea $(16.5 \%, 5.2 \%, 2.1 \%$ ) (Table 4); EPEC and ETEC prevalence was higher in pilgrims who had no diarrhea $(37.1 \%, 4.1 \%)$ 
Table 4

Frequency of pathogens in post-Hajj samples according to diarrhea.

\begin{tabular}{lllll} 
& $\begin{array}{l}\text { No diarrhea } \\
(\mathrm{N}=97)\end{array}$ & $\begin{array}{l}\text { Diarrhea } \\
(\mathrm{N}=15)\end{array}$ & $\begin{array}{l}\text { Ongoing } \\
\text { diarrhea } \\
(\mathrm{N}=6)\end{array}$ & $\begin{array}{l}\text { Resolved } \\
\text { diarrhea } \\
(\mathrm{N}=9)\end{array}$ \\
\hline $\begin{array}{lllll}\text { Clostridium difficile } \\
\text { EAEC }^{\mathrm{a}}\end{array}$ & $1(1.0)$ & 0 & 0 & 0 \\
EPEC $^{\mathrm{b}}$ & $16(16.5)$ & $5(33.3)$ & 0 & $5(55.6)$ \\
ETEC $^{\mathrm{c}}$ & $36(37.1)$ & $4(26.7)$ & $1(16.7)$ & $3(33.3)$ \\
STEC $^{\mathrm{d}}$ & $4(4.1)$ & 0 & 0 & 0 \\
At least one & $5(5.2)$ & $3(20.0)$ & $1(16.7)$ & $2(22.2)$ \\
$\quad 47(48.5)$ & $7(46.7)$ & $2(33.3)$ & $5(55.6)$ \\
$\quad$ bacteria & & & & $1(11.1)$ \\
At leavis one virus & $2(2.1)$ & $1(6.7)$ & 0 & $1(11.1)$ \\
At least one & $48(49.5)$ & $8(53.3)$ & $2(33.3)$ & $6(66.7)$ \\
$\quad$ & & & &
\end{tabular}

\footnotetext{
a Enteroaggregative Escherichia coli.

b Enteropathogenic E. coli.

c Enterotoxigenic E. coli.

d Shigella/enteroinvasive E. coli.
}

compared to those who had diarrhea $(26.7 \%, 0)$. These differences however, were not statistically significant. The highest pathogen prevalence was that of EAEC with a rate of $55.6 \%$ in pilgrims with resolved diarrhea against $16.5 \%$ in pilgrims without diarrhea $[\mathrm{OR}=6.23$; $95 \%$ CI (1.53-26.18); $\mathrm{P}=0.014]$. 4 out of 9 patients with resolved diarrhea and EAEC in post-Hajj samples were already positive in pre-Hajj samples.

The effect of the use of hand gel, of enhanced hand washing and of antibiotic intake during travel on the prevalence of diarrhea and of pathogen carriage in post-Hajj samples was investigated. We found no significant association in most instances with the exception of a lower prevalence of EPEC (22.5\%) in pilgrims who declared washing their hands more frequently than usually compared to others $(40.0 \%)$, [OR $=0.34 ; 95 \%$ CI $(0.15-0.78) ; \mathrm{P}=0.017]$

\section{Discussion}

We observed a relatively high rate of EAEC (17.5\%) and EPEC (14.0\%) carriage in asymptomatic pilgrims before they traveled to KSA, in marked contrast with recent findings describing rates of $1-2 \%$ in pretravel stools of non-Hajj Finish travelers using a validated qPCR multiplex assay [10]. Hajj pilgrims from Marseille mostly originate from North Africa and undergo frequent travels between France and the Maghreb [11], which may account for this result [12].

We evidenced a high acquisition rate of bacterial pathogens $(43.5 \%)$ following the pilgrims' stay in KSA. EPEC, EAEC and STEC were the most frequent $E$. coli pathotypes acquired at the Hajj. Of note, a significant 29.6\% EPEC acquisition rate was reported. By contrast, we found a relatively low rate of diarrhea in pilgrims during the $2016 \mathrm{Hajj}$ $(13.7 \%)$. This result is in line with those obtained during previous Hajj seasons (2008-2015) in French pilgrims where the prevalence of diarrhea ranged from $4.5 \%$ to $23.3 \%[8,13]$. This is the first prospective study providing information on the acquisition of gastrointestinal pathogens at the Hajj pilgrimage using a method that allows the identification of a large panel of potential enteric pathogens. EAEC and STEC were found more frequently in pilgrims who suffered diarrhea at the Hajj and this was statistically significant for EAEC detection in pilgrims with resolved diarrhea. This finding corroborates recent research where EAEC have been reported to be frequently associated with diarrhea in travelers returning from various geographical areas [10,14-17]. By contrast, in a Saudi study conducted in hospitalized Hajj pilgrims suffering diarrhea in 2011-2013, EAEC was found in only few patients $(1.3 \%)$, while Salmonella, ETEC and EIEC were found in respectively in $11.4 \%, 8.8 \%$ and $7.5 \%$ of patients and were mostly associated with severe diseases [3].
Our study has several limitations including notably an overall small number of subjects. Participants of this study traveled together, staying in the same hotels and tents during their sojourn, and eating the same food during a five day-period of time in Mina, Arafat and Muzdhalifa which could potentially hamper the generalisability of the microbiological findings. Self-sampling by pilgrims may have been sub-optimal. The sample type used is not FDA cleared or CE marked and the FilmArray GI panel performance characteristics using self-collected rectal swabs have not been established. Additionally, detection rates may have been biased by the swab's potential small sample volume leading to variation in detection rates for pathogens present at the limit of detection of the assay. The number of pilgrims suffering from diarrhea in our cohort was small and likely accounts for the absence of statistical association between symptoms and detection of other pathotypes including ETEC, which is also considered as the major pathogen involved in traveler's diarrhea [18]. On the other hand, the overall detection rates for most pathogens were similar between symptomatic patients with resolved or ongoing diarrhea and asymptomatic controls. This may be explained either by asymptomatic colonization or by prolonged nucleic acid shedding in the absence of viable pathogens. Confirmation of PCR-positive specimens by microscopy or culture-based techniques might be necessary to prove active, clinically relevant infections with vital pathogens [19].

The acquisition of $E$ coli by Hajj pilgrims is concerning. The prevalence of third-generation cephalosporin-resistant bacteria is common in KSA [20]. We previously reported that the rates of CTX-M genes in French pilgrims were $31.0 \%$ following the 2013 Hajj and 34.8\% in 2014 Hajj, with diarrhea and use of $\beta$-lactam antibiotics during the event being independent risk factors of CTX-M gene acquisition [20]. CTX-M genes were found in $33.3 \%$ of ETEC infections associated with the Hajj in Saudi hospitals [3]. Therefore, pilgrims are at an increased risk of acquisition of antibiotic resistant enteric bacteria and may carry and transfer these bacteria when returning to their home countries.

Pilgrims should be educated regarding measures to prevent traveler's diarrhea and the development and transmission of antibiotic-resistant bacteria including the importance of hygiene practices and appropriate antibiotics use [20]. Frequent hand washing was associated with lower carriage of EPEC following the Hajj in this study. Frequent hand washing with soap is a simple measure that should be encouraged among pilgrims.

Further studies aiming at evaluating the effect of such intervention on incidence of diarrhea and acquisition of pathogens in a larger cohort of pilgrims are needed. Recruiting a larger international cohort of pilgrims representing different continents and cultures could possibly allow identify key risk factors and preventative strategies. Also, environmental studies with the aim of identifying potential sources of contamination are warranted.

\section{Acknowledgement}

This work was supported by bioMérieux and by the Agence Nationale de la Recherche (programme "investissement d'avenir" Méditerranée Infection 10-IAHU-03).

\section{References}

[1] Abubakar I, Gautret P, Brunette GW, Blumberg L, Johnson D, Poumerol G, Memish ZA, Barbeschi M, Khan AS. Global perspectives for prevention of infectious diseases associated with mass gatherings. Lancet Infect Dis 2012 Jan;12(1):66-74. http://dx. doi.org/10.1016/S1473-3099(11)70246-8.

[2] Gautret P, Benkouiten S, Sridhar S, Al-Tawfiq JA, Memish ZA. Diarrhea at the Hajj and umrah. Trav Med Infect Dis 2015 Mar-Apr;13(2):159-66.

[3] Abd El Ghany M, Alsomali M, Almasri M, Padron Regalado E, Naeem R, Tukestani A, Asiri A, Hill-Cawthorne GA, Pain A, Memish ZA. Enteric infections circulating during Hajj seasons, 2011-2013. Emerg Infect Dis 2017 Oct;23(10):1640-9.

[4] Gautret P, Benkouiten S, Parola P, Brouqui P, Memish Z, Raoult D. Occurrence of Tropheryma whipplei during diarrhea in Hajj pilgrims: a PCR analysis of paired rectal swabs. Trav Med Infect Dis 2014 Sep-Oct;12(5):481-4. 
[5] Olaitan AO, Dia NM, Gautret P, Benkouiten S, Belhouchat K, Drali T, Parola P, Brouqui P, Memish Z, Raoult D, Rolain JM. Acquisition of extended-spectrum cephalosporin- and colistin-resistant Salmonella enterica subsp. enterica serotype Newport by pilgrims during Hajj. Int J Antimicrob Agents 2015 Jun;45(6):600-4.

[6] Leangapichart T, Dia NM, Olaitan AO, Gautret P, Brouqui P, Rolain JM. Acquisition of extended-spectrum B-lactamases by Escherichia coli and Klebsiella pneumoniae in gut microbiota of pilgrims during the Hajj pilgrimage of 2013. Antimicrob Agents Chemother 2016 Apr 22;60(5):3222-6.

[7] Leangapichart T, Gautret P, Brouqui P, Mimish Z, Raoult D, Rolain JM. Acquisition of mcr-1 plasmid-mediated colistin resistance in Escherichia coli and Klebsiella pneumoniae during Hajj 2013 and 2014. Antimicrob Agents Chemother 2016 Oct 21;60(11):6998-9.

[8] Leangapichart T, Gautret P, Griffiths K, Belhouchat K, Memish Z, Raoult D, Rolain JM. Acquisition of a high diversity of bacteria during the Hajj pilgrimage, including Acinetobacter baumannii with blaOXA-72 and Escherichia coli with blaNDM-5 carbapenemase genes. Antimicrob Agents Chemother 2016 Sep 23;60(10):5942-8.

[9] Leangapichart T, Tissot-Dupont H, Raoult D, Memish ZA, Rolain JM, Gautret P. Risk factors for acquisition of CTX-M genes in pilgrims during Hajj 2013 and 2014. J Antimicrob Chemother 2017 Sep 1;72(9):2627-35.

[10] Lääveri T, Pakkanen SH, Antikainen J, Riutta J, Mero S, Kirveskari J, Kantele A. High number of diarrhoeal co-infections in travellers to Benin, West Africa. BMC Infect Dis 2014 Feb 12;14:81.

[11] Gautret P, Bauge M, Simon F, Benkouiten S, Parola P, Brouqui P. Travel reported by pilgrims from Marseille, France before and after the 2010 Hajj. J Trav Med 2012 Mar-Apr;19(2):130-2.

[12] Vading M, Kabir MH, Kalin M, Iversen A, Wiklund S, Nauclér P, Giske CG. Frequent acquisition of low-virulence strains of ESBL-producing Escherichia coli in travellers.
J Antimicrob Chemother 2016 Dec;71(12):3548-55. Epub 2016 Aug 26.

[13] Gautret P, Benkouiten S, Sridhar S, Al-Tawfiq JA, Memish ZA. Diarrhea at the Hajj and umrah. Trav Med Infect Dis 2015 Mar-Apr;13(2):159-66.

[14] Antikainen J, Kantele A, Pakkanen SH, Lääveri T, Riutta J, Vaara M, Kirveskari J. A quantitative polymerase chain reaction assay for rapid detection of 9 pathogens directly from stools of travelers with diarrhea. Clin Gastroenterol Hepatol 2013 Oct;11(10):1300-7. e3.

[15] Paredes-Paredes M, Okhuysen PC, Flores J, Mohamed JA, Padda RS, GonzalezEstrada A, Haley CA, Carlin LG, Nair P, DuPont HL. Seasonality of diarrheagenic Escherichia coli pathotypes in the US students acquiring diarrhea in Mexico. J Trav Med 2011 Mar-Apr;18(2):121-5.

[16] Paschke C, Apelt N, Fleischmann E, Perona P, Walentiny C, Löscher T, Herbinger $\mathrm{KH}$. Controlled study on enteropathogens in travellers returning from the tropics with and without diarrhoea. Clin Microbiol Infect 2011 Aug;17(8):1194-200.

[17] Lääveri T, Antikainen J, Pakkanen SH, Kirveskari J, Kantele A. Prospective study of pathogens in asymptomatic travellers and those with diarrhoea: aetiological agents revisited. Clin Microbiol Infect 2016 Jun;22(6):535-41.

[18] Steffen R, Hill DR, DuPont HL. Traveler's diarrhea: a clinical review. J Am Med Assoc 2015 Jan 6;313(1):71-80.

[19] Becker SL, Chatigre JK, Gohou JP, Coulibaly JT, Leuppi R, Polman K, Chappuis F, Mertens P, Herrmann M, N'Goran EK, Utzinger J, von Müller L. Combined stoolbased multiplex PCR and microscopy for enhanced pathogen detection in patients with persistent diarrhoea and asymptomatic controls from Côte d'Ivoire. Clin Microbiol Infect 2015 Jun;21(6):591.

[20] Leangapichart T, Rolain JM, Memish ZA, Al-Tawfiq JA, Gautret P. Emergence of drug resistant bacteria at the Hajj: a systematic review. Trav Med Infect Dis 2017 Jul - Aug;18:3-17. 